\title{
連載企画「最前線の現場」の連載にあたって
}

\author{
小野寺 真一 $* 1$
}

\section{Introduction of research frontiers in hydrology}

\author{
Shin-ichi ONODERA*1
}

「最前線の現場」とは，まさに限られた専門家 のみが知り得る最新の情報を, 当事者の研究の新 規性を損なわない範囲で速報的に発信していただ くという，日本水文科学会の特徵の一つである フットワークの軽さを最大限に活かした企画で す。緊急度の高い現場，新規性の高い現場，災害 が発生したばかりの現場などの現場発信型の企画 から, 最新の機器, 試験地, 研究室などの紹介, 始まったばかりの研究プロジェクトの概要紹介な どのまさに最先端紹介型まで，広く読者の皆様に とって興奮と緊張感を感じさせるものを提供して いきたいと考えております。また，現場での計測 にまつわる話題，とくに研究論文ではあまり触れ られない計測上の失敗談を公表することで，他研 究者が同様の失敗を繰り返さないように情報を共 有することも念頭に置いております。

昨今，水文科学に関わる，または周辺の分野に 打いて様々な極端現象（津波災害，放射能污染， 火山噴火，豪雨災害，異常渴水等）が発生し，ま た関連して污染や地盤沈下など様々な事象も発生 しており，驚かされることが少なくありません。 例えば，昨年（2014年）の8月20日未明に広島 市北部で発生した集中豪雨は，極めて局地的であ りながら大きな土砂災害を引き起こしました。ま た，今年 (2015年) のゴールデンウィークに活 発化した箱根大涌谷での火山活動は，周辺地域を 立ち入り禁止にするなど温泉観光地に大きな影響
を及ぼしました。これらの情報の多くは, 報道関 係者による映像や文字の情報に限られ，必ずしも 科学的な観察に基づくものは多いとはいえませ ん。しかし，実際にその現場に立って観察してい る研究者，行政官，コンサルタントの方々がいる はずです。このような情報は研究論文等として公 表されないこともあり，あるいは論文等になった としても発行・出版までのプロセスを経るために 緊急性や速報性は低くなっている場合も見受けら れます。すなわち，学会誌といえども速報性や緊 急性に軸足を置いた情報発信も重要だと考えま す。他方, 多くの研究現場では，常に最新の機器 や手法を取り入れながら研究を推進しているはず です。これらも最前線（三最先端）の現場といえ るでしょうし，研究としての新規性に抵触しない 可能な範囲で情報提供ができることは，多くの読 者にとって有益であると考えられます。

本学会の会員数自体は少ないものの, 掲載記事 はJ-stageを通じて無料で世界に公表されており， 読者の潜在数は他のオンラインジャーナルと差が ありません。読者に魅力的であると同時に，科学 的に価值の高い記事を増やしてゆけば，読者数は 増えてゆくものと確信して打ります。企画原稿を 広く公募いたします。皆様からの投稿を編集委員 会一同持待ちしております。どうぞよろしくお願 いいたします。

* 1 広島大学大学院総合科学研究科 Graduate school of Integrated Arts and Sciences, Hiroshima University 